\title{
Copper phytotoxicity in agricultural crops cultivated in tropical soils
}

\section{Fitotoxicidade do cobre em culturas agrícolas cultivadas em solos tropicais}

\author{
Mateus Moreira Engelhardt ${ }^{1}$; Francielle Roberta Dias de Lima ${ }^{2}$; Gabriel Caixeta \\ Martins $^{3}$; Isabela Cristina Filardi Vasques ${ }^{4}$; Aline Oliveira Silva ${ }^{3}$; Jakeline Rosa \\ Oliveira $^{2}$; Rayner Hugo Cassa Louzada dos Reis²; Luiz Roberto Guimarães \\ Guilherme ; João José Granate de Sá e Melo Marques ${ }^{5 *}$
}

\section{Highlights:}

$\mathrm{Cu}$ is more toxic to plant species in Typic Hapludox.

Rice is the species most sensitive to $\mathrm{Cu}$ in soils.

It is expected that soils with $60 \mathrm{mg} \mathrm{kg}^{-1}$ of $\mathrm{Cu}$ may keep the development of plants.

\begin{abstract}
Copper is a micronutrient for living organisms, but at high concentrations it may cause several deleterious effects. The objective of this study was to evaluate the behavior of agricultural crops to different concentrations of $\mathrm{Cu}$ in the soil. The species Triticum aestivum (wheat), Zea mays (maize), Oryza sativa (rice), Phaseolus vulgaris (dry bean), Glycine max (soybean), and Raphanus sativus (radish) were cultivated in the soils Typic Hapludox (TyHpx) and Rhodic Acrudox (RhAcx). The experiment was carried out in a greenhouse and the soils were set in pots in a completely randomized design, with four replicates per treatment adding the following $\mathrm{Cu}$ concentrations (as $\mathrm{Cu}$-nitrate): 0, 75, $150,300,600,800,1000,1200 \mathrm{mg} \mathrm{kg}^{-1}$ dry soil. Measurements of biological variables, such as shoot dry weight (SDW), plant height, stem diameter, and number of leaves were carried out, in addition to determining $\mathrm{Cu}$ content in the SDW. At the TyHpx, a decreasing order of tolerance to $\mathrm{Cu}$ phytotoxicity was: dry bean, maize, soybean, wheat, radish, and rice. However, at the RhAcx, the decreasing order was: maize, soybean, radish, wheat, dry bean, and rice. The species that revealed the highest sensitivity to high $\mathrm{Cu}$ concentrations in soil was rice and that with the lowest sensitivity was maize.
\end{abstract}

Key words: Copper nitrate. Ecotoxicology. Micronutrient. Contamination.

1 M.e, Programa de Pós-Graduação em Ciência do Solo, Universidade Federal de Lavras, UFLA, Lavras, MG, Brasil. E-mail: mateusme1@hotmail.com

2 Discentes do Curso de Doutorado do Programa de Pós-Graduação em Ciência do Solo, UFLA, Lavras, MG, Brasil. E-mail: frandislim@gmail.com; oliveirajakeline791@gmail.com; rayner15@gmail.com

3 Drs., Programa de Pós-Graduação em Ciência do Solo, UFLA, Lavras, MG, Brasil. E-mail: gcm_eng@yahoo.com.br; alineoliveirasilva6@gmail.com

4 Profa Dra, Departamento de Solos, Universidade Federal de Viçosa, UFV. Viçosa, MG, Brasil. E-mail: isabela.filardi@ufv.br

5 Profs. Drs., Departamento de Ciência do Solo, Programa de Pós-Graduação em Ciência do Solo, UFLA, Lavras, MG, Brasil. E-mail: guilherm@ufla.br.jmarques@ufla.br

* Author for correspondece 


\section{Resumo}

O cobre é um micronutriente para organismos vivos, mas em altas concentrações pode causar vários efeitos deletérios. O objetivo deste estudo foi avaliar o comportamento de culturas agrícolas em diferentes concentrações de $\mathrm{Cu}$ no solo. As espécies Triticum aestivum (trigo), Zea mays (milho), Oryza sativa (arroz), Phaseolus vulgaris (feijão), Glycine max (soja) e Raphanus sativus (rabanete) foram cultivadas nos solos Latossolo Vermelho Amarelo distrófico típico (LVAd) e Latossolo Vermelho distroférrico típico (LVdf). O experimento foi realizado em casa de vegetação e os solos foram colocados em vasos, em delineamento inteiramente casualizado, com quatro repetições por tratamento, adicionando às seguintes concentrações de $\mathrm{Cu}$ (como nitrato de $\mathrm{Cu}$ ): 0, 75, 150, 300, 600, 800, 1000, $1200 \mathrm{mg} \mathrm{kg}^{-1}$ de solo seco. Foram realizadas medidas das variáveis biológicas matéria seca da parte aérea (MSPA), altura da planta, diâmetro do caule e número de folhas, além disso foi determinado o teor de $\mathrm{Cu}$ na MSPA. No LVAd, a ordem decrescente de tolerância à fitotoxicidade do $\mathrm{Cu}$ foi: feijão, milho, soja, trigo, rabanete e arroz. No entanto, no LVdf, a ordem decrescente foi: milho, soja, rabanete, trigo, feijão e arroz. A espécie que revelou maior sensibilidade às altas concentrações de $\mathrm{Cu}$ no solo foi o arroz e a que apresentou menor sensibilidade foi o milho.

Palavras-chave: Nitrato de cobre. Ecotoxicidade. Micronutriente. Contaminação.

\section{Introduction}

Soil protection, that is, to protect its diversity and ecological functions, has become an objective of environmental agencies around the world (Bone et al., 2010). Predict the possible consequences that a particular contaminant may cause in the environment is a need for decision making in contaminated sites management (Niva et al., 2016). The evaluation of ecotoxicological risks is based on a complex process of collecting, organizing, and analyzing environmental data to estimate adverse effects caused by contamination (Caetano, Marques, Gonçalves, Silva, \& Pereira, 2016).

The relations between the contaminant source, exposure, and effects on organisms are complex and often specific to a particular location, since the environmental conditions and affected organisms are also specific. Therefore, ecotoxicological risk assessment should be site-specific to provide reliable information for decision-making (Jensen \& Mesman, 2006). In such studies, the effects of varying concentrations of a substance on the biological variables of living organisms are evaluated. The results can be shown in calculated ecotoxicity parameters or indexes, such as the NOAEL (no observed adverse effect level),
LOAEL (lowest observed adverse effect level), ECx (concentration that reduces $x \%$ compared to the control treatment), and $\mathrm{HCy}$ (hazardous concentration to $y \%$ of the species) (Caetano et al., 2016; Verbruggen, Posthumus, \& Van Wezel, 2001).

Successive agricultural management practices, such as soil fertilization and liming, and application of agricultural pesticides during the crop cycle, alongside the long period of cultivation in certain areas, may result in large amounts of metals added to soils, such as $\mathrm{Cu}$. Copper is a micronutrient for plants acting on assorted metabolic processes, as member of several enzymes that catalyze the electron flow and oxidation reactions in plant cells (Yruela, 2005). However, at high concentrations, $\mathrm{Cu}$ in plants can cause disturbances in vegetative cells, such as inducing oxidative stress, which is determined by reactive oxygen species (ROS) formation and reduction in nutrient absorption, promoting considerable losses in productivity (Mantovani, 2009; Santos, Melo, Luz, \& Tomasi, 2004; Toselli et al., 2008).

Some studies in Brazil have confirmed contamination with $\mathrm{Cu}$ in sites with intensive longterm agriculture and the contamination of soils with $\mathrm{Cu}$-based pesticides has become a concern. Girotto 
et al. (2016) observed that vineyards in the South of Brazil, had $\mathrm{Cu}$ contents above $400 \mathrm{mg} \mathrm{kg}^{-1}$ in the soil after 30 years of cultivation, significantly affecting the physiology of black oat. Some studies were conducted in order to reduce soil $\mathrm{Cu}$ availability in Brazilian vineyards. Ferreira et al. (2018) studied the application of limestone (3 Mg ha $\left.^{-1}\right)$, Ca-silicate (3 $\left.\mathrm{Mg} \mathrm{ha}^{-1}\right)$, and vermicompost (30 $\mathrm{g} \mathrm{C} \mathrm{kg}^{-1}$ of dry soil) to the soil to reduce $\mathrm{Cu}$ toxicity. They observed vermicompost was more efficient in reducing toxicity of $\mathrm{Cu}$ to the plants, since $\mathrm{Cu}$ is easily complexed with soil organic matter (SOM). High $\mathrm{Cu}$ concentrations in soils were also reported in areas with mango (Mangifera indica) trees, cultivated for more than 26 years in Pernambuco State (Silva, Nascimento, Biondi \& Cunha, 2012), and with melon (Cucumis melo), cultivated for two years in Rio Grande do Norte State (Mendes, Duda, Nascimento, Lima, \& Medeiros, 2010). In both cases, $\mathrm{Cu}$ contents were higher than the prevention value $\left(60 \mathrm{mg} \mathrm{kg}^{-1}\right.$ ) allowed by the Brazilian legislation (Conselho Nacional do Meio Ambiente [CONAMA], 2009) for $\mathrm{Cu}$ in soils.

Soil characteristics, such as texture and SOM, directly affect $\mathrm{Cu}$ mobility in soils. Gharbi, Rejeb, Ghorbal and Morel (2005) observed greater transfer of $\mathrm{Cu}$ from soil to plant in a sandy loam than in a clay loam. These authors also found a difference in $\mathrm{Cu}$ toxicity between the species Lactuca sativa (lettuce) and Spinacia oleracea (spinach), with the latter being more affected by $\mathrm{Cu}$. Copper accumulation also differed between plant organs, for instance, lettuce accumulated nearly 60 to $80 \%$ of the $\mathrm{Cu}$ in its roots (Gharbi et al., 2005). Cavani, Manici, Caputo, Peruzzi and Ciavatta (2016) reported alterations in the composition of bacterial communities, as well as decrease in biomass and microbial activities of the soil in Italian vineyards contaminated by the excessive use of cupric products. Lejon, Pascault and Ranjard (2010) also observed that $\mathrm{Cu}$ reduced bacterial diversity in soils with low organic matter content, but with the increase of SOM, there was a decrease in this deleterious effect. With the increase of SOM there is the favoring of the formation of chelating agents in the soil, which complex the $\mathrm{Cu}$, restricting its bioavailability (Ambrosini et al., 2015). Therefore, establishing relationships between soil characteristics and concentrations of $\mathrm{Cu}$ that can affect plants is extremely important for the most appropriate agricultural management.

This study aimed to verify the effect of $\mathrm{Cu}$ nitrate in six crops: maize, rice, wheat, soybean, dry bean, and radish cultivated in two tropical soils. We also aimed to study how $\mathrm{Cu}$-contaminated soils are able to influence growth variables for the studied species and the extension of $\mathrm{Cu}$ transfer to shoots.

\section{Material and Methods}

\section{Ecotoxicology tests}

The phytotoxicity tests were performed according to ISO 11.269-2 (International Organizations for Standardization [ISO], 2012). This standard protocol aims not to reproduce field situations, but rather to assess what happens at a worst-case contamination condition. Three monocotyledons were selected: Triticum aestivum cv. BRS 264 (wheat), Zea mays cv. RB 9004 PRO 2 (maize), and Oryza sativa cv. BRS Esmeralda (rice); and also three eudicotyledons: Phaseolus vulgaris L. cv. Madrepérola (dry bean), Glycine max cv. BRS 284 (soybean), and Raphanus sativus cv. Crimson Gigante (radish). These plants are widely cultivated throughout the world and the cultivars used in this study are commercial varieties found in Brazil.

Each experimental unit was made of a $500 \mathrm{~cm}^{3}$ pot filled with soil samples taken from the $0-20 \mathrm{~cm}$ depth of commonly found (in wet tropical zones of the Earth) soil types: a Typic Hapludox (TyHpx) $\left(21^{\circ} 13^{\prime} 30^{\prime \prime} \mathrm{S}\right.$ and 44$\left.{ }^{\circ} 57^{\prime} 38^{\prime \prime} \mathrm{W}\right)$ and a Rhodic Acrudox (RhAcx) $\left(21^{\circ} 09^{\prime} 18^{\prime \prime} \mathrm{S}\right.$ and $45^{\circ} 05^{\prime} 55^{\prime \prime}$ W) (Table 1) (Soil Survey Staff, 2014). Both soil samples were collected at the Lavras County, Minas Gerais State, Brazil. The soil samples were taken under natural vegetation (semideciduous tropical 
rainforest), had low $\mathrm{Cu}$ content, and had not undergone visible major human impact.

The soil samples were ground, air dried, and successively sieved through 5 and $2 \mathrm{~mm}$ meshes. The samples were subsequently characterized and used in phytotoxicity tests. The particle size analysis was performed by the pipette method (Almeida et al., 2012). The chemical characterization of soils was performed according to the methods proposed by Teixeira, Donagemma, Fontana and Teixeira (2017). Cupper was determined according to United States Environmental Protection Agency [USEPA] (2007), method 3051A. The soil physical and chemical characteristics are presented in Table 1.

\section{Table 1}

Chemical and physical properties of the Typic Hapludox (TyHpx) and Rhodic Acrudox (RhAcx) soils (0-0.2 m) used in this study

\begin{tabular}{|c|c|c|c|c|c|c|c|c|c|}
\hline \multirow{2}{*}{ Soils } & \multicolumn{9}{|c|}{ Properties } \\
\hline & $\mathrm{pH}^{\mathrm{a}}$ & $\mathrm{Al}$ & $\mathrm{H}+\mathrm{Al}$ & $\mathrm{CEC}^{\mathrm{b}}$ at $\mathrm{pH} 7.0$ & O.M. $^{\mathrm{c}}$ & Clay & Silt & Sand & $\mathrm{Cu}$ \\
\hline & \multicolumn{4}{|c|}{ - } & \multicolumn{4}{|c|}{------------ g kg-1 ---------- } & $\mathrm{mg} \mathrm{kg}^{-1}$ \\
\hline ТуHрх & 4.9 & 0.4 & 3.9 & 6.1 & 21.1 & 310 & 110 & 580 & 28.1 \\
\hline RhAcx & 4.4 & 1.2 & 11.1 & 11.7 & 39.9 & 680 & 130 & 190 & 9.6 \\
\hline
\end{tabular}

${ }^{\mathrm{a}} \mathrm{pH}$ in water 1:2.5 soil:solution; ${ }^{\mathrm{b}}$ Cation exchange capacity; ${ }^{\mathrm{c}}$ Soil organic matter.

Fertilization was performed according to the critical level required for soils (Alvarez \& Ribeiro, 1999) and minimum levels required for fertilization in pots (Malavolta, 1981). Watering was made throughout the experiment to keep water content at $60 \%$ of the total soil pore volume. Seventy-two hours after fertilization, different $\mathrm{Cu}$ concentrations were added to the soil $(0,75,150,300,600,800$, 1000 , and $1200 \mathrm{mg} \mathrm{kg}^{-1}$ ) by different aliquots of a $\mathrm{Cu}\left(\mathrm{NO}_{3}\right)_{2}$ solution, following the guidelines of ISO 11.269-2 (ISO, 2012). Soils were then homogenized and incubated for 24 hours before sowing as suggested by ISO 11.269-2 (ISO, 2012). Ten seeds were sown per pot. After seedling emergence, the number of plants was reduced to six. The experiment lasted 21 days, after emergence of $50 \%$ of the control treatment.

\section{Evaluation of biological variables}

Seedling emergence was evaluated as suggested by Maguire (1962) and at the end of the experiment the following vegetative growth variables were measured: shoot height (determined by graded rule), stem diameter (measured with digital caliper), number of leaves, and shoot dry weight (determined on a precision scale, after $70^{\circ} \mathrm{C}$ in a forced circulation oven until constant weight).

\section{Copper concentration in shoots}

The $\mathrm{Cu}$ concentration in plant material was determined according to USEPA (2007) method 3051A. Samples of approximately $0.5 \mathrm{~g}$ of dried plant material were milled in Wiley mill, then placed with $5.0 \mathrm{~mL}$ of concentrated $\mathrm{HNO}_{3}$ into Teflon ${ }^{\circledR}$ vessels that were hermetically sealed and heated in a Mars-5 microwave digestion oven (CEM Corp, Matthews, NC) for 10 minutes. The still sealed vessels were removed from the oven and cooled to room temperature under a fume hood. After opening the vessels, the volume was added up to $10 \mathrm{~mL}$ with bidistilled water. The $\mathrm{Cu}$ concentration was determined in a graphite furnace atomic absorption 
spectrophotometer. In each batch of material analyzed, one reference sample, with known and certified $\mathrm{Cu}$ content (NIST SRM 1573a - tomato leaves), was analyzed, as well as a blank sample, in order to ensure quality control and to calculate the method detection limit (MDL) (Penha et al., 2017).

\section{Statistical analysis}

For statistical proposes, each experiment consisted of one soil type and one plant species. The pots were in a completely randomized design, with four replicates per treatment. Biological variables were submitted to variance analysis $(p \leq$ 0.05 ), followed by regression analysis ( $p \leq 0.05$ ). Normality and variance homogeneity were checked by Kolmogorov-Smirnov and Bartlett tests, respectively. The NOAEL (no observed adverse effect level) and LOAEL (lowest observed adverse effect level) values were determined by the Dunnet test $(p \leq 0.05)$.

$\mathrm{EC}_{\mathrm{x}}$ values (concentration that reduces $x \%$ compared to the control treatment) and their 95\% confidence limits were calculated for the following variables: emergence, plant height, stem diameter, and shoot dry weight using the nonlinear regression models: Gompertz, Hormesis, and Logistic, inserted in the software Statistica, version 7.0. (Statsoft, 2004). The model that revealed the best determination coefficient $\left(R^{2}\right)$ at 95\% significance was used. These statistical models were used only for those data sets characterized by decreasing trends of values upon $\mathrm{Cu}$ addition (Environment Canada [EC], 2005; Rocheleau et al., 2010). The $\mathrm{EC}_{\mathrm{x}}$ values of shoot dry weight (SDW) were used for calculating the $\mathrm{HC}_{5}$ values (hazardous concentration to $5 \%$ of the species) through species sensitivity distribution (SSD) curves fit by ETX 2.0 software (Van Vlaardingen, Traas, Wintersen, \& Aldenberg, 2004) at 95\% significance.

\section{Results and Discussion}

All tested species were sensitive to $\mathrm{Cu}$, since there was a reduction in the tested variables (emergence, height, stem diameter, number of leaves, and SDW) for both soils (Table 2), particularly for emergence and SDW (Figures 1 and 2). However, the sensitivity of each species was rather different due to morphophysiological characteristics of each species, such as cell wall thickness, root structure type and enzymatic defense mechanisms (Yruela, 2005).

In general, the emergence of monocotyledons showed a significant reduction after addition of $75 \mathrm{mg} \mathrm{kg}^{-1}$ of $\mathrm{Cu}$ (Table 2). For eudicotyledons, a significant reduction was observed after addition of $300 \mathrm{mg} \mathrm{kg}^{-1}$ of $\mathrm{Cu}$ (Table 2). According to Luchese, Gonçalves, Luchese and Braccini (2004), there is a decrease in the emergence of maize, a monocotyledon, as the concentration of $\mathrm{Cu}$ in soil increases. Singh, Nath and Sharma (2007) observed that $\mathrm{Cu}$ at high concentrations reduces the emergence and plant growth mainly due to inhibiting and reducing the activity of amylase, the enzyme responsible for the metabolization of starch present in the seed reserves used to generate energy for the germination process. In spite of the deleterious effects of $\mathrm{Cu}$ concentrations in soils, the eudicotyledons presented higher resistance to $\mathrm{Cu}$ at lower concentrations, $<300 \mathrm{mg} \mathrm{kg}^{-1}$. Eudicotyledons are known for having seeds with the high starch reserves (Li, Li, Dunwell, \& Zhang, 2012). On the other hand, according to Caetano et al. (2016), monocotyledons were less sensitive to concentrations of $\mathrm{Cu}$ in the soil (maximum concentration ranging from 497 to $951 \mathrm{mg} \mathrm{Cu}$ per $\mathrm{kg}$ of soil). The authors listed the species they studied in a decreasing order of $\mathrm{Cu}$ sensitivity: Lactuca sativa $>$ Lycopersicon esculentum $>$ Zea mays $>$ Avena sativa. The lowest sensitivity of the monocotyledons presented by Caetano et al. (2016) does not match the results of the present study, possibly due to soil or varietal differences. 
Table 2

NOAEL (no observed adverse effect level) and LOAEL (lowest observed adverse effect level) values according to phytotoxicological tests on maize, rice, wheat, soybean, radish, and dry bean in Typic Hapludox (TyHpx) and Rhodic Acrudox (RhAcx) with increasing concentrations of $\mathrm{Cu}$. This table only shows data that followed normal distribution and were significant at $5 \%$ probability for Dunnett's test

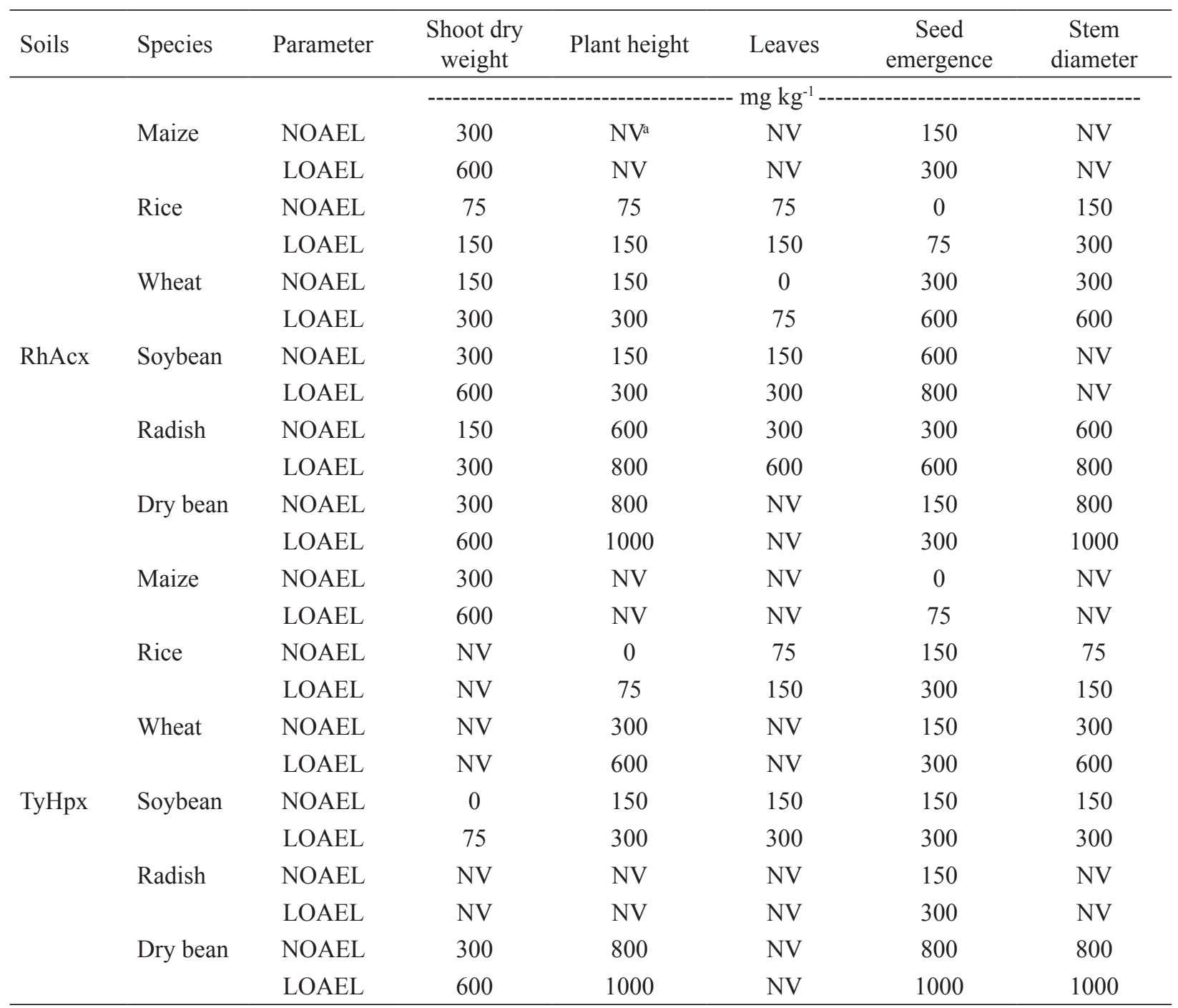

${ }^{a} \mathrm{NV}$ - Data not validated by ANOVA and Dunnett's test $(\mathrm{p}<0.05)$.

The SDW was sensitive to increases of $\mathrm{Cu}$ concentrations in the two soil types and in all species evaluated. A significant reduction in the SDW of the monocotyledons grown in TyHpx is observed from the concentration of $300 \mathrm{mg} \mathrm{kg}^{-1}$ (Figure 2), while the plants cultivated in RhAcx showed sensitivity at concentrations higher than $400 \mathrm{mg} \mathrm{kg}^{-1}$ (Figure 2). Regarding SDW, it was observed, just as in seed emergence, that eudicotyledons were more tolerant to $\mathrm{Cu}$ than the monocotyledons, particularly at higher concentrations. 


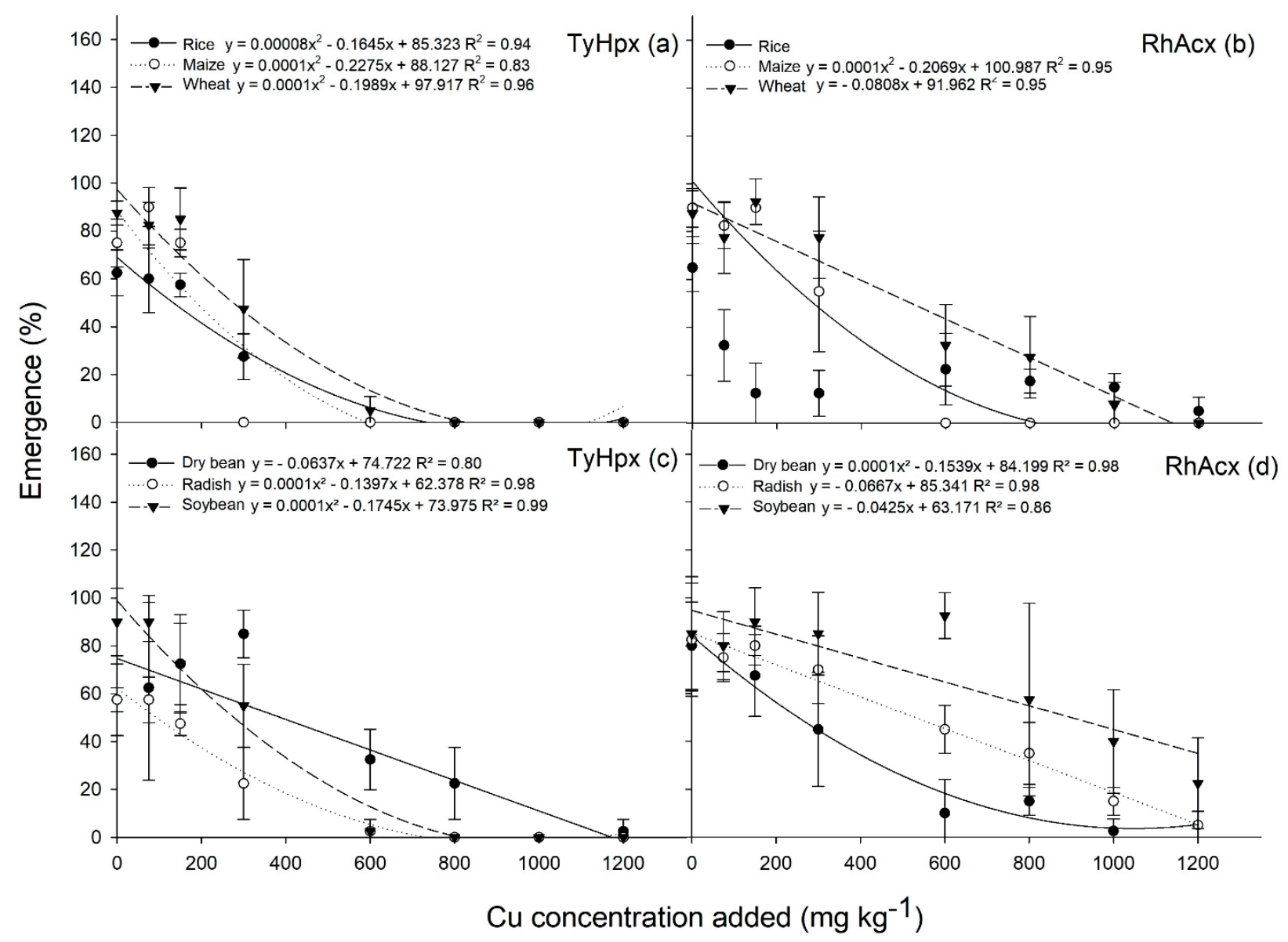

Figure 1. Seed emergence for rice, maize, wheat, dry bean, radish, and soybean after cultivation with increasing concentrations of $\mathrm{Cu}$ in Typic Hapludox (TyHpx) and Rhodic Acrudox (RhAcx). Vertical lines represent standard errors where they exceed the height of symbols. Points without error bars have standard errors smaller than the symbols.

Other vegetative growth variables, in addition to seed emergence and SDW, are recommended by ISO 11.269-2 (ISO, 2012) for ecotoxicological studies. Thus, evaluation of plant height and stem diameter was performed. Shoot height reduced with increasing $\mathrm{Cu}$ concentrations in both soil types. At lower concentrations of $\mathrm{Cu}$, the species were not negatively affected (Table 2), because of the $\mathrm{Cu}$ being is a plant nutrient with beneficial effects at lower concentrations. However, despite $\mathrm{Cu}$ being a plant nutrient, when in high concentrations, there are deleterious effects of the plants, as we observed in the monocotyledons (after addition of $75 \mathrm{mg} \mathrm{kg}^{-1}$ ) and in the eudicotyledons (after addition of $300 \mathrm{mg}$ $\left.\mathrm{kg}^{-1}\right)$.
Higher concentrations of $\mathrm{Cu}$ (Figure 3) in plant tissues were observed from the concentration of 300 mg kg-1 upwards. The species cultivated in TyHpx showed higher accumulation (Figure 4) even when growing less. The $\mathrm{Cu}$ content in SDW for some species almost doubled when comparing TyHpx with RhAcx. This effect is probably related to lower levels of clay and organic matter in the former. Clay and organic matter content are crucial for the soil buffering capacity in relation to metals (Nascimento $\&$ Fontes, 2004). Higher of organic matter, high CEC and high $\mathrm{pH}$ reduce the phytotoxic effect of $\mathrm{Cu}$ in soil (Li, Zhang, Ma, \& McLaughlin, 2011; Cavani et al., 2016). But, beyond the soil's characteristics, plants can actively change their biochemical systems. 


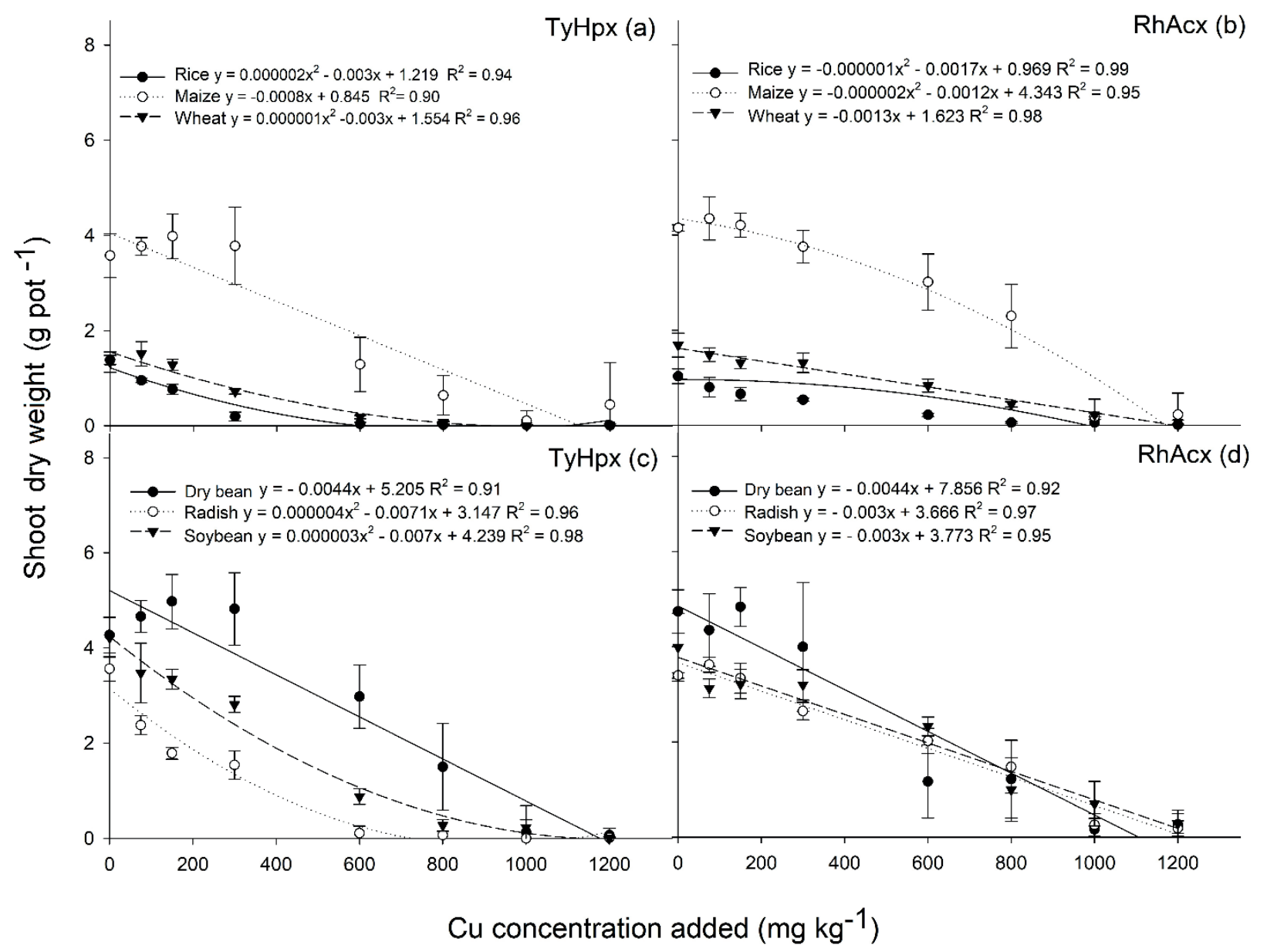

Figure 2. Shoot dry weight production for rice, maize, wheat, dry bean, radish, and soybean after cultivation with increasing concentrations of $\mathrm{Cu}$ in Typic Hapludox (TyHpx) and Rhodic Acrudox (RhAcx). Vertical lines represent standard errors where they exceed the height of symbols. Points without error bars have standard errors smaller than the symbols.

According to Guo, Zuo, Wang, Li and Ma (2010), $\mathrm{Cu}$ is a low mobile element in maize plants and $\mathrm{Cu}$ contents were found by them in the following order: leaf $>$ stem $>$ grains. The low mobility of $\mathrm{Cu}$ in plants led those authors to state that the presence of $\mathrm{Cu}$ in the soils they studied was not so worrying, because they demonstrated that, even under high application rates of $\mathrm{Cu}$ in soil (as $\mathrm{CuCl}_{2}-800$ and 3,200 mg $\left.\mathrm{kg}^{-1}\right)$. In our study, not all plant species could keep $\mathrm{Cu}$ concentrations in reduced levels in their tissues. According to Kabata-Pendias and Szteke (2015), doses of 20 and $100 \mathrm{mg} \mathrm{kg}^{-1}$ in SDW are already considered toxic for some species like citrus and legumes. Fatnassi, Chiboub, Saadani, Jebara and Jebara (2015) observed that Vicia faba plants grown in solution with $1 \mathrm{mM} \mathrm{Cu}$ responded metabolically with enzyme activation linked to the antioxidant activity of superoxide dismutase, catalase and ascorbate peroxidase, which increased $\mathrm{Cu}$ tolerance since the increase in the concentration of this metal may result in considerable losses in plant growth and production potential, with reduction in chlorophyll production and nitrate reduction (Luna, Casano, \& Trippi, 1997). 


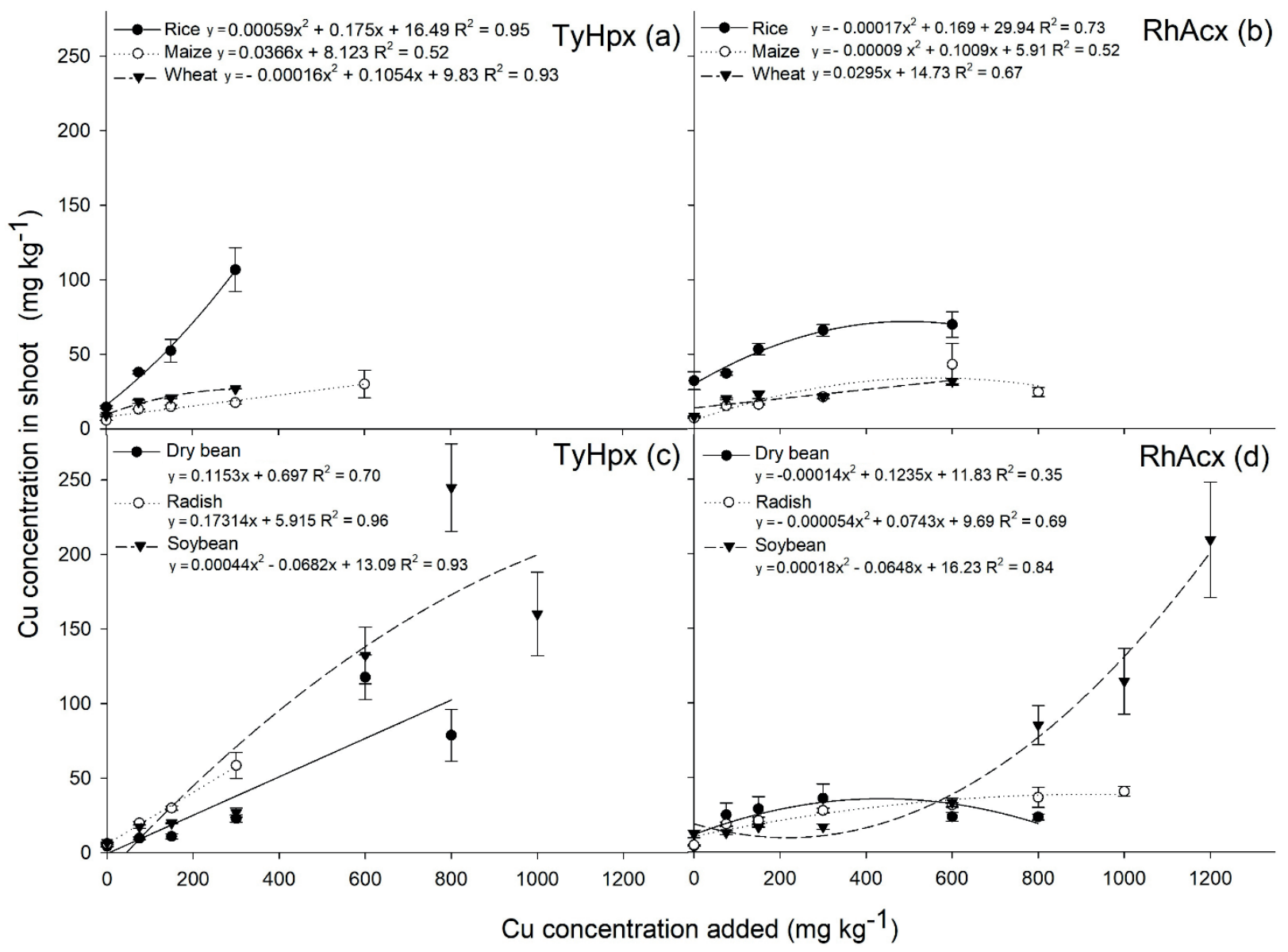

Figure 3 Copper concentration in plants (above ground tissue) of rice, maize, wheat, dry bean, radish, and soybean after cultivation with increasing concentrations of $\mathrm{Cu}$ in Typic Hapludox (TyHpx) and Rhodic Acrudox (RhAcx). Vertical lines represent standard errors where they exceed the height of symbols. Points without error bars have standard errors smaller than the symbols.

The values of NOAEL and LOAEL are shown in Table 2 and may be used in further ecotoxicological studies. However, some authors suggest that the evaluation of ecotoxicology based on NOAEL and LOAEL is not the best approach because these values are largely dependent on the concentrations used in each experiment, by the variability of data, by the level of significance, and by the sample size (Warne \& Van Dam, 2008).

The values of $\mathrm{EC}_{50}, \mathrm{EC}_{20}$, and $\mathrm{EC}_{10}$ varied widely between soils and plant species (Table 3), as they determine a specific concentration of effect and are not based on nominal treatment values. These fractions (50, 20 and 10\% effect) were selected because they are commonly used in ecotoxicology studies (Caetano et al., 2016; Hale et al., 2017). For the TyHpx, a decreasing sequence of tolerance to $\mathrm{Cu}$ phytotoxicity, evaluated by $\mathrm{EC}_{50}$ for SDW, was: dry bean, maize, soybean, wheat, radish, and rice. However, at the RhAcx, the decreasing sequence was: maize, soybean, radish, wheat, dry bean, and rice (Figure 5). Based on our data, the most sensitive species to $\mathrm{Cu}$ was rice and the least were maize and soybean, with one exception observed for emergence in TyHpx. Xu et al. (2006) reported than rice is strongly affected by $\mathrm{Cu}$ in soils. According to them, yield was reduced about $10 \%$ at $100 \mathrm{mg} \mathrm{kg}^{-1}$ of $\mathrm{Cu}$; about $50 \%$ at $300-500 \mathrm{mg} \mathrm{kg}^{-1}$; 
and about $90 \%$ at a $\mathrm{Cu}$ concentration of $1000 \mathrm{mg}$ $\mathrm{kg}^{-1}$ applied to soil. Similar results were found in the present study, as the $\mathrm{EC}_{50}$ (for SDW) was found to be $270 \mathrm{mg} \mathrm{kg}^{-1}$ of $\mathrm{Cu}$. It is noteworthy that different sensitivity rates for the same species can be related to different cultivars, since Fageria (2007) found that rice was the most resistant species among soybean, wheat, common bean and corn, being able to show symptoms of toxicity only after $51 \mathrm{mg} \mathrm{kg}^{-1}$ of $\mathrm{Cu}$ in soils, but a different cultivar was used.

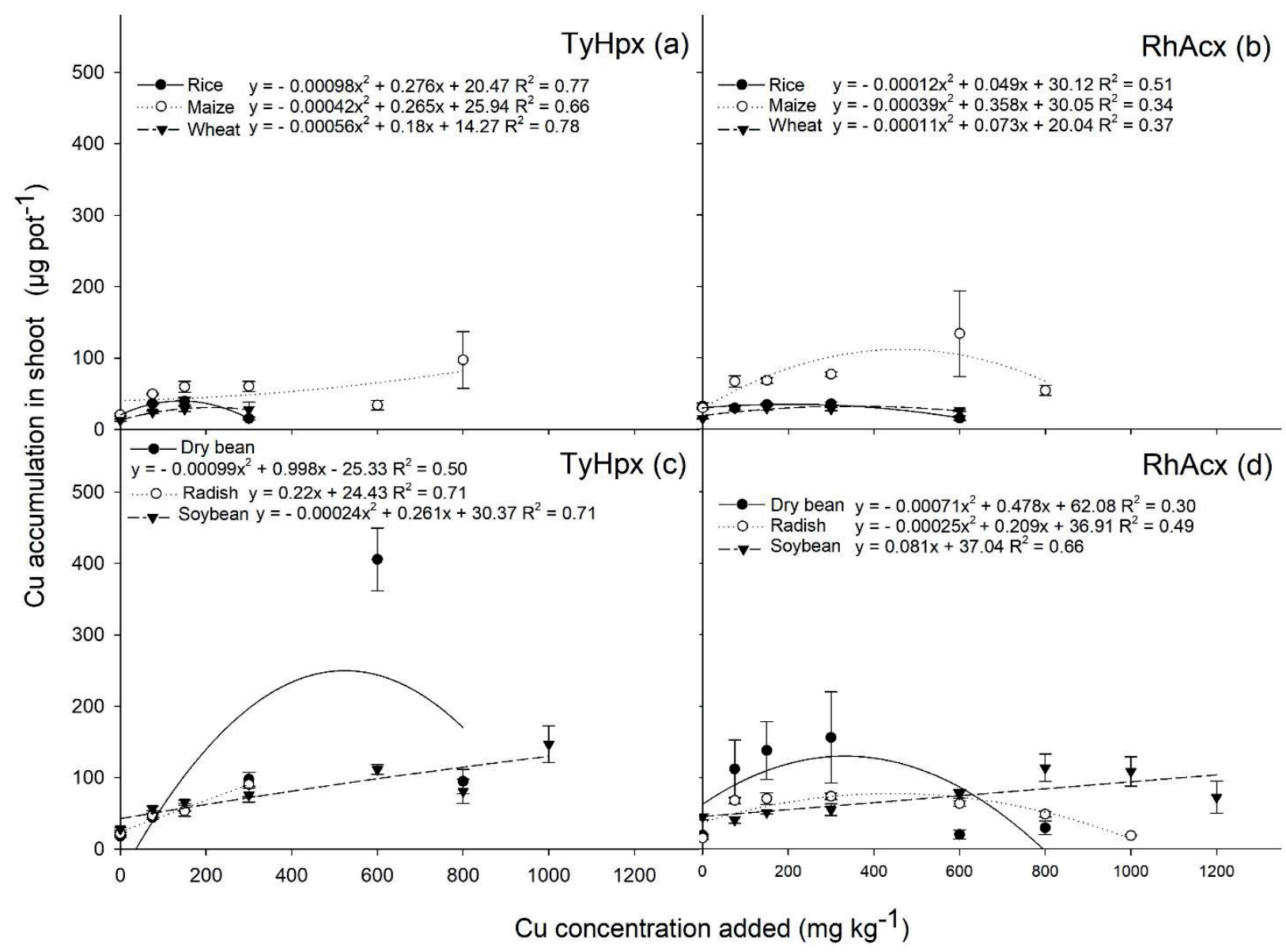

Figure 4 Copper accumulation in above ground plant material of rice, maize, wheat, dry bean, radish, and soybean after cultivation with increasing concentrations of $\mathrm{Cu}$ in Typic Hapludox (TyHpx) and Rhodic Acrudox (RhAcx). Vertical lines represent standard errors where they exceed the height of symbols. Points without error bars have standard errors smaller than the symbols. 
Table 3

$\mathrm{EC}_{50}, \mathrm{EC}_{20}$, and $\mathrm{EC}_{10}$ (concentrations that reduces 50, 20, and $10 \%$ of the variable compared to the control treatment) values according to phytotoxicological tests on maize, rice, wheat, soybean, radish, and dry bean cultivated in Typic Hapludox (TyHpx) and Rhodic Acrudox (RhAcx) with increasing concentrations of $\mathrm{Cu}$. This table shows data that followed normal distribution and were significant at $5 \%$ probability for non-linear regressions, \pm standard deviation of the means

\begin{tabular}{|c|c|c|c|c|c|c|c|c|c|}
\hline \multirow{3}{*}{ Variable } & \multirow{3}{*}{ Species } & \multicolumn{4}{|c|}{ RhAcx } & \multicolumn{4}{|c|}{ TyHрx } \\
\hline & & $\mathrm{EC}_{50}$ & $\mathrm{EC}_{20}$ & $\mathrm{EC}_{10}$ & $\begin{array}{c}\mathrm{R}^{2} \\
\left(\mathrm{EC}_{50}\right)\end{array}$ & $\mathrm{EC}_{50}$ & $\mathrm{EC}_{20}$ & $\mathrm{EC}_{10}$ & $\begin{array}{c}\mathrm{R}^{2} \\
\left(\mathrm{EC}_{50}\right)\end{array}$ \\
\hline & & \multicolumn{3}{|c|}{ - } & $\%$ & \multicolumn{3}{|c|}{ - - } & $\%$ \\
\hline \multirow{6}{*}{ Emergence } & Maize & $284 \pm 87$ & $192 \pm 22$ & $\mathrm{NV}^{\mathrm{a}}$ & 94 & $179 \pm 74$ & $45 \pm 23$ & $\mathrm{NV}$ & 90 \\
\hline & Rice & $61 \pm 36$ & $32 \pm 20$ & $25 \pm 16$ & 84 & $242 \pm 69$ & $47 \pm 33$ & $\mathrm{NV}$ & 95 \\
\hline & Wheat & $569 \pm 57$ & $227 \pm 23$ & $113 \pm 12$ & 92 & $314 \pm 30$ & $236 \pm 48$ & $199 \pm 60$ & 98 \\
\hline & Soybean & $896 \pm 87$ & $720 \pm 124$ & $634 \pm 149$ & 87 & $331 \pm 52$ & $204 \pm 59$ & $148 \pm 62$ & 97 \\
\hline & Radish & $639 \pm 64$ & $255 \pm 26$ & $127 \pm 12$ & 92 & $254 \pm 40$ & $165 \pm 45$ & $128 \pm 47$ & 97 \\
\hline & Dry bean & $335 \pm 109$ & $150 \pm 94$ & $88 \pm 75$ & 92 & $651 \pm 134$ & $478 \pm 215$ & $390 \pm 259$ & 84 \\
\hline \multirow{6}{*}{ Height } & Maize & $\mathrm{NV}$ & NV & $\mathrm{NV}$ & - & $878 \pm 46$ & $773 \pm 68$ & $710 \pm 85$ & 95 \\
\hline & Rice & $639 \pm 49$ & $255 \pm 20$ & $127 \pm 10$ & 95 & $276 \pm 29$ & $139 \pm 24$ & $93 \pm 21$ & 99 \\
\hline & Wheat & $825 \pm 66$ & $330 \pm 26$ & $165 \pm 13$ & 96 & $501 \pm 72$ & $318 \pm 70$ & $268 \pm 76$ & 96 \\
\hline & Soybean & $766 \pm 50$ & $306 \pm 20$ & $153 \pm 10$ & 97 & $526 \pm 28$ & $335 \pm 37$ & $248 \pm 39$ & 99 \\
\hline & Radish & $868 \pm 58$ & $651 \pm 86$ & $562 \pm 131$ & 95 & $455 \pm 58$ & $297 \pm 73$ & $224 \pm 75$ & 97 \\
\hline & Dry bean & $949 \pm 185$ & $654 \pm 238$ & $546 \pm 340$ & 76 & $760 \pm 144$ & $304 \pm 58$ & $152 \pm 29$ & 81 \\
\hline \multirow{6}{*}{$\begin{array}{l}\text { Stem } \\
\text { diameter }\end{array}$} & Maize & $\mathrm{NV}$ & $\mathrm{NV}$ & $\mathrm{NV}$ & - & $913 \pm 61$ & $783 \pm 105$ & $707 \pm 135$ & 91 \\
\hline & Rice & $855 \pm 110$ & $342 \pm 44$ & $171 \pm 22$ & 90 & $350 \pm 62$ & $123 \pm 39$ & $67 \pm 28$ & 97 \\
\hline & Wheat & $1121 \pm 140$ & $522 \pm 143$ & $333 \pm 143$ & 93 & $588 \pm 42$ & $235 \pm 17$ & $117 \pm 9$ & 96 \\
\hline & Soybean & $1106 \pm 60$ & $860 \pm 102$ & $728 \pm 133$ & 90 & $714 \pm 28$ & $565 \pm 46$ & $484 \pm 127$ & 98 \\
\hline & Radish & $863 \pm 68$ & $620 \pm 88$ & $514 \pm 103$ & 95 & $551 \pm 51$ & $220 \pm 20$ & $110 \pm 20$ & 93 \\
\hline & Dry bean & $701 \pm 115$ & $280 \pm 46$ & $140 \pm 23$ & 84 & $914 \pm 85$ & $787 \pm 121$ & $721 \pm 149$ & 83 \\
\hline \multirow{6}{*}{ Leaves } & Maize & $\mathrm{NV}$ & $\mathrm{NV}$ & $\mathrm{NV}$ & - & $\mathrm{NV}$ & $\mathrm{NV}$ & $\mathrm{NV}$ & - \\
\hline & Rice & $469 \pm 92$ & $118 \pm 53$ & $47 \pm 30$ & 97 & $299 \pm 44$ & $106 \pm 28$ & $58 \pm 20$ & 98 \\
\hline & Wheat & $\mathrm{NV}$ & $523 \pm 53$ & $261 \pm 26$ & 95 & $673 \pm 84$ & $248 \pm 23$ & $124 \pm 12$ & 90 \\
\hline & Soybean & $893 \pm 102$ & $357 \pm 41$ & $178 \pm 21$ & 92 & $566 \pm 30$ & $226 \pm 12$ & $113 \pm 6$ & 97 \\
\hline & Radish & $\mathrm{NV}$ & $665 \pm 125$ & $470 \pm 145$ & 93 & $492 \pm 75$ & $282 \pm 12$ & $195 \pm 83$ & 96 \\
\hline & Dry bean & $\mathrm{NV}$ & $\mathrm{NV}$ & $\mathrm{NV}$ & - & $\mathrm{NV}$ & $\mathrm{NV}$ & $\mathrm{NV}$ & - \\
\hline \multirow{6}{*}{$\begin{array}{l}\text { Shoot dry } \\
\text { weight }\end{array}$} & Maize & $635 \pm 61$ & $254 \pm 25$ & $127 \pm 13$ & 93 & $534 \pm 72$ & $412 \pm 78$ & $373 \pm 84$ & 95 \\
\hline & Rice & $270 \pm 70$ & $92 \pm 46$ & $45 \pm 31$ & 96 & $148 \pm 18$ & $61 \pm 15$ & $34 \pm 12$ & 98 \\
\hline & Wheat & $597 \pm 37$ & $239 \pm 15$ & $119 \pm 7$ & 97 & $303 \pm 34$ & $129 \pm 47$ & $112 \pm 38$ & 98 \\
\hline & Soybean & $630 \pm 59$ & $252 \pm 24$ & $126 \pm 12$ & 94 & $516 \pm 41$ & $206 \pm 16$ & $103 \pm 8$ & 94 \\
\hline & Radish & $610 \pm 40$ & $244 \pm 16$ & $122 \pm 8$ & 96 & $188 \pm 33$ & $54 \pm 11$ & $21 \pm 13$ & 97 \\
\hline & Dry bean & $335 \pm 109$ & $150 \pm 94$ & $88 \pm 75$ & 92 & $651 \pm 134$ & $478 \pm 215$ & $390 \pm 250$ & 84 \\
\hline
\end{tabular}

${ }^{a} \mathrm{NV}$ - Data not validated by non-linear regression models $(\mathrm{p}<0.05)$. 


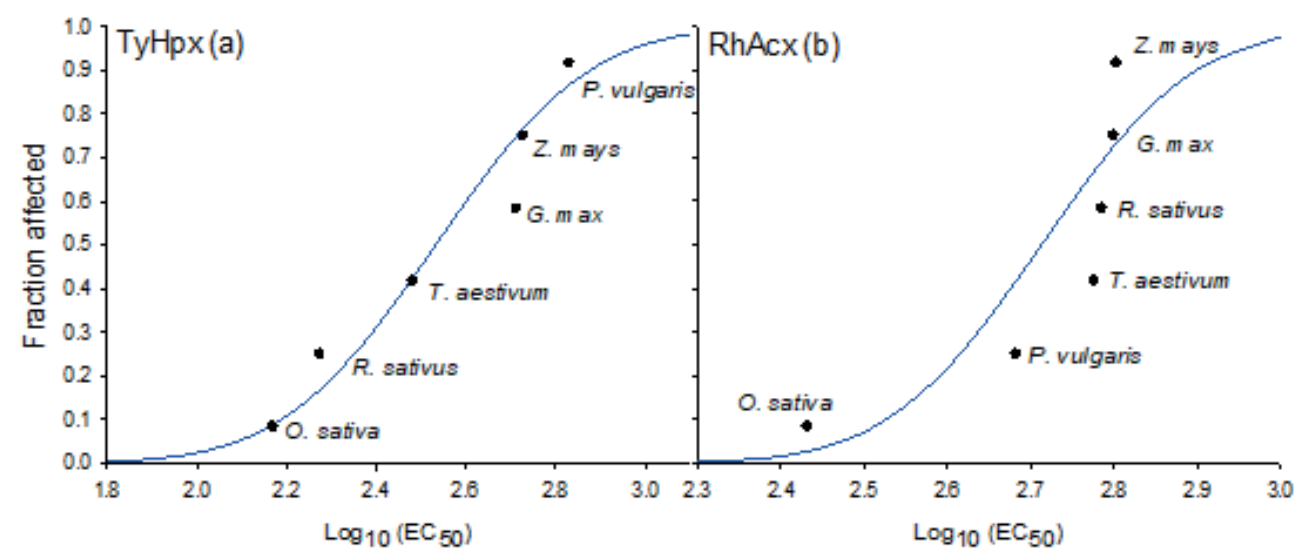

Figure 5 Species sensitivity distribution (SSD) curves built from $\mathrm{EC}_{50}$ of shoot dry weight for the soils Typic Hapludox (TyHpx) (a) and Rhodic Acrudox (RhAcx) (b).

Seed emergence was the variable with the highest variation among species and SDW the least variable. The variation in seed emergence between plant species may be related, if even in a small extent, to the nutritional reserve content of the seed (Bezerra, Momenté, \& Medeiros, 2004; Marcos \& Kikuti, 2006) and not the environmental conditions. Therefore, SDW is the best choice for building SSD curves. Besides, it was decided to present only SSDs built with $\mathrm{EC}_{50}$ values for avoidance graphic redundancy. Generally, it was observed a trend for higher $\mathrm{EC}_{\mathrm{x}}$ values in RhAcx, compared to TyHpx. This may be due to higher values of CEC, clay, and SOM in the former. These variables can affect $\mathrm{Cu}$ availability because they may act as adsorbents (Kabata-Pendias \& Szteke, 2015). According to Rooney, Zhao and McGrath (2006) the CEC is one of the soil properties that has greatest relation with $\mathrm{Cu}$ toxicity. Thus, for RhAcx, probably a lower proportion of the applied $\mathrm{Cu}$ was available in the soil solution to cause toxicity.

The values of $\mathrm{HC}_{5}$ (hazardous concentration to $5 \%$ of the species) were determined for the SDW (Table 4) based on the SSD curves. It was not possible to estimate $\mathrm{HC}_{5}$ values for $\mathrm{RhAcx}$ because the data did not pass normality tests as the values for $\mathrm{EC}_{\mathrm{x}}$ were very similar for the species tested (Figure 5b). On the other hand, the $\mathrm{EC}_{\mathrm{x}}$ values obtained for the $\mathrm{RhAcx}$ were used to derive $\mathrm{HC}_{5}$ for both soils (using the mean of ECx for each species) and although the $\mathrm{HC}_{5}$ values tended to be higher than those obtained TyHpx, it should be noted that confidence intervals overlap.

\section{Table 4}

$\mathrm{HC}_{5}$ values in Typic Hapludox (TyHpx), Rhodic Acrudox (RhAcx) and both soils (RhAcx + TyHpx) based on EC $_{x}$ values for shoot dry weight

\begin{tabular}{cccc}
\hline & \multicolumn{3}{c}{$\mathrm{HC}_{5}$} \\
\cline { 2 - 4 } $\mathrm{EC}_{\mathrm{x}}$ & $\mathrm{RhAcx}^{\mathrm{a}}$ & $\mathrm{TyHpx}$ & $\mathrm{RhAcx}+\mathrm{TyHpx}$ \\
\cline { 2 - 4 } & $\mathrm{NV}^{\mathrm{b}}$ & $116.6 \pm 81.4$ & $220 \pm 107$ \\
\hline $\mathrm{EC}_{50}$ & $\mathrm{NV}$ & $31.6 \pm 39.7$ & $74.3 \pm 48.7$ \\
$\mathrm{EC}_{20}$ & $\mathrm{NV}$ & $12.6 \pm 23.4$ & $33.5 \pm 28.5$ \\
$\mathrm{EC}_{10}$ & &
\end{tabular}

${ }^{a}$ For each species, the $\mathrm{EC}_{\mathrm{x}}$ from each soil was averaged and used to estimate the $\mathrm{HC}_{5}$.

${ }^{\mathrm{b}} \mathrm{NV}$ - not validated in the normality test (the Anderson-Darling test, Kolmogorov-Smirnov test, Cramer von Mises test). 
The experiments that evaluate the effects of $\mathrm{Cu}$ as nutrient use lower concentrations of $\mathrm{Cu}$, because as shown by our results, greater concentration of $\mathrm{Cu}$ can be toxic. Moreira \& Moraes (2019), for example, tested a maximum $\mathrm{Cu}$ concentration of $8 \mathrm{mg} \mathrm{kg}^{-1}$ in soybeans, but the greatest grain yield was achieved at $\mathrm{Cu}$ concentrations of $4 \mathrm{mg} \mathrm{kg}^{-1}$. Studies that focus in evaluating the toxic effects of $\mathrm{Cu}$ use greater $\mathrm{Cu}$ concentrations, such ours and Fageria (2007), where tested up to $96 \mathrm{mg} \mathrm{kg}^{-1}$ of $\mathrm{Cu}$ in rice, common bean, soybean, wheat and corn crops.

The current maximum legal $\mathrm{Cu}$ concentration used by environmental agencies in Brazil, called "prevention value", is $60 \mathrm{mg} \mathrm{kg}{ }^{-1}$. Up to this concentration, Brazilian soils are supposed to maintain their main ecological functions, like the capability to grown plants (CONAMA, 2009; Conselho Estadual de Política Ambiental [COPAM], 2011). The results of the present study suggest that the current Brazilian prevention value for $\mathrm{Cu}$ is effective to ensure plant development. This claim is supported by $\mathrm{HC}_{5}$ values calculated for TyHpx and for both soils (Table 4). Although $60 \mathrm{mg} \mathrm{kg}^{-1}$ of $\mathrm{Cu}$ in the soil already leads to loss of plant growth, as shown in Table 5 using the prediction with the linear regression equations shown in Figure 2, the calculated $\mathrm{HC}_{5}$ values for $\mathrm{EC}_{50}$ are higher than the current Brazilian prevention value for $\mathrm{Cu}$. Thus, in a Brazilian soil with $60 \mathrm{mg} \mathrm{kg}^{-1}$ of $\mathrm{Cu}$, a plant development of at least $50 \%$ may be expected for $95 \%$ of the species grown in such soil.

\section{Table 5}

Prediction of the loss of shoot dry weight using the the linear regression equations of rice, maize, wheat, dry bean, radish, and soybean cultivated in Typic Hapludox (TyHpx) and Rhodic Acrudox (RhAcx) with an addition of $60 \mathrm{mg} \mathrm{kg}^{-1}$ of $\mathrm{Cu}$

\begin{tabular}{|c|c|c|c|c|c|c|}
\hline \multirow{2}{*}{$\begin{array}{l}\mathrm{Cu} \text { added in soil } \\
\qquad\left(\mathrm{mg} \mathrm{kg}^{-1}\right)\end{array}$} & Rice & Maize & Wheat & Dry bean & Radish & Soybean \\
\hline & \multicolumn{6}{|c|}{ shoot dry weight $\left(\mathrm{g} \mathrm{pot}^{-1}\right)$ - TyHpx } \\
\hline 0 & 1.219 & 0.845 & 1.554 & 5.205 & 3.147 & 4.239 \\
\hline \multirow[t]{4}{*}{60} & 1.046 & 0.797 & 1.378 & 4.941 & 2.735 & 3.830 \\
\hline & \multicolumn{6}{|c|}{ shoot dry weight losses (\%) } \\
\hline & -14.18 & -5.68 & -11.35 & -5.07 & -13.08 & -9.65 \\
\hline & \multicolumn{6}{|c|}{ shoot dry weight $\left(\mathrm{g} \mathrm{pot}^{-1}\right)-\mathrm{RhAcx}$} \\
\hline 0 & 0.967 & 4.343 & 1.623 & 7.856 & 3.666 & 3.773 \\
\hline \multirow[t]{3}{*}{60} & 0.971 & 4.264 & 1.545 & 7.592 & 3.486 & 3.593 \\
\hline & \multicolumn{6}{|c|}{ shoot dry weight losses (\%) } \\
\hline & -0.37 & -1.82 & -4.81 & -3.36 & -4.91 & -4.77 \\
\hline
\end{tabular}

\section{Conclusions}

The species most sensitive to $\mathrm{Cu}$ was rice and the least were maize and soybean. The soil properties can intensify or decrease symptoms of toxicity, since $\mathrm{Cu}$ is more toxic to plant species in Typic Hapludox. This effect can be related to the buffering effect of the clay and organic matter contents on metals toxicity. The current maximum legal $\mathrm{Cu}$ concentration for the prevention value used by environmental agencies in Brazil, $60 \mathrm{mg} \mathrm{kg}^{-1}$, is protective enough for the tested species. 


\section{Funding information}

Authors would like to thank the Coordenação de Aperfeiçoamento de Pessoal de Nível Superior (CAPES), Conselho Nacional de Desenvolvimento Científico e Tecnológico (CNPq) and the Fundação de Amparo à Pesquisa do Estado de Minas Gerais (FAPEMIG) for the overall finantial support during experiment and for the scholarship provided.

\section{References}

Almeida, B. G., Donagemma, G. K., Ruiz, H. A., Braida, J. A., Viana, J. H. M., Reichert, J. M. M.,... Teixeira, W. G. (2012). Padronização de métodos para análise granulométrica no Brasil. Rio de Janeiro, RJ: EMBRAPA Solos.

Alvarez, V. H. \& Ribeiro, A. C. (1999). Calagem. In: V. H. Alvarez, P. T. G. Guimarães, \& A. C. Ribeiro (Eds.), Recomendações para o uso de corretivos e fertilizantes em Minas Gerais (pp. 43-60). Viçosa, MG: CFSEMG.

Ambrosini, V. G., Voges, J. G., Canton, L., Couto, R. D. R., Ferreira, P. A. A., Comin, J. J.,... Soares, C. R. F. S. (2015). Effect of arbuscular mycorrhizal fungi on young vines in copper-contaminated soil. Brazilian Journal of Microbiology, 46(4), 1045-1052. doi: 10.1590/S1517-838246420140622

Bezerra, A. M. E., Momenté, V. G., \& Medeiros, S., Fº (2004). Germinação de sementes e desenvolvimento de plântulas de moringa (Moringao leifera Lam.) em função do peso da semente e do tipo de substrato. Horticultura Brasileira, 22(2), 295-299. doi: 10.1590/S0102-05362004000200026

Bone, J., Head, M., Barraclough, D., Archer, M., Scheib, C., Flight, D., \& Voulvoulis, N. (2010). Soil quality assessment under emerging regulatory requirements. Environment International, 36(6), 609-622. doi: 10.1016/j. envint. 2010. 04. 010

Caetano, A. L., Marques, C. R., Gonçalves, F., Silva, E. F. da, \& Pereira, R. (2016). Copper toxicity in a natural reference soil: ecotoxicological data for the derivation of preliminary soil screening values. Ecotoxicology, 25(1), 163-177. doi: 10.1007/s10646015-1577-7

Cavani, L., Manici, L. M., Caputo, F., Peruzzi, E., \& Ciavatta, C. (2016). Ecological restoration of a copper polluted vineyard: Long-term impact of farmland abandonment on soil bio-chemical properties and microbial communities. Journal of Environmental Management, 182(1), 37-47. doi: 10.1016/j.jenvman. 2016.07. 050

Conselho Estadual de Política Ambiental (2011). Deliberação Normativa $n^{\circ} 166$ de 29 de junho de 2011. Diário do Executivo - 27 de Julho de 2011. Belo Horizonte: COPAM.

Conselho Nacional do Meio Ambiente (2009). Resolução $n^{\circ} 420$ de 28 de dezembro de 2009. Diário Oficial da União $n^{\circ}$ 249. Brasília: Ministério do Meio Ambiente.

Environment Canada (2005). Report EPS 1/RM/46. Guidance document on statistical methods for environmental toxicity tests. Ottawa: EC.

Fageria, N. K. (2007). Adequate and toxic levels of copper and manganese in upland rice, common bean, corn, soybean, and wheat grown on an Oxisol. Communications in Soil Science and Plant Analysis, 32(9), 1659-1676. doi: 10.1081/CSS-100104220

Fatnassi, I. C., Chiboub, M., Saadani, O., Jebara, M., \& Jebara, S. H. (2015). Impact of dual inoculation with Rhizobium and PGPR on growth and antioxidant status of Vicia faba L. under copper stress. Comptes Rendus Biologies, 338(4), 241-254. doi: 10.1016/j. crvi.2015.02.001

Ferreira, P. A. A., Marchezan, C., Ceretta, C. A., Tarouco, C. P., Lourenzi, C. R., Silva, L. S.,... Brunetto, G. (2018). Soil amendment as a strategy for the growth of young vines when replanting vineyards in soils with high copper content. Plant Physiology and Biochemistry, 126(1), 152-162. doi: 10.1016/j. plaphy. 2018.03.003

Gharbi, F., Rejeb, S., Ghorbal, M. H., \& Jean-Louis, M. (2005). Plant response to copper toxicity as affected by plant species and soil type. Journal of Plant Nutrition, 28(3), 379-392. doi: 10.1081/PLN200049147

Girotto, E., Ceretta, C. A., Rossato, L. V., Farias, J. G., Brunetto, G., Miotto, A.,... Nicoloso, F. T. (2016). Biochemical changes in black oat (Avena strigosa Schreb) cultivated in vineyard soils contaminated with copper. Plant Physiology and Biochemistry, 103(1), 199-207. doi: 10.1016/j.plaphy.2016.02.030

Guo, X. Y., Zuo, Y. B., Wang, B. R., Li, J. M., \& Ma, Y. B. (2010). Toxicity and accumulation of copper and nickel in maize plants cropped on calcareous and acidic field soils. Plant Soil, 333(1), 365-373. doi: 10.1007/s11104-010-0351-0 
Hale, B., Gopalapillai, Y., Pellegrino, A., Jennett, T., Kikkert, J., Lau, W.,... McLaughlin, M. J. (2017). Validation of site-specific soil Ni toxicity thresholds with independent ecotoxicity and biogeochemistry data for elevated soil Ni. Environmental Pollution, 231(1), 165-172. doi: 10.1016/j.envpol.2017.08.008

International Organizations for Standardization (2012). Soil quality-determination of the effects of pollutants on soil flora - Part 2: effects of contaminated soil on the emergence and early growth of higher plants, $n^{\circ}$ 11269-2. Geneva: ISO.

Jensen, J., \& Mesman, M. (2006). Ecological risk assessment of contaminated land: decision support for site specific investigations. New York, NY: RIVM.

Kabata-Pendias, A., \& Szteke, B. (2015). Trace elements in abiotic and biotic environments. New York, NY: CRC Press.

Lejon, D. P. H., Pascault, N., \& Ranjard, L. (2010). Differential copper impact on density, diversity and resistance of adapted culturable bacterial populations according to soil organic status. European Journal of Soil Biology, 46(2), 168-174. doi: 10.1016/j. ejsobi.2009.12.002

Li, B., Zhang, H., Ma, Y., \& McLaughlin, M. J. (2011). Influences of soil properties and leaching on nickel toxicity to barley root elongation. Ecotoxicology and Environmental Safety, 74(3), 459-466. doi: 10. 1016/j.ecoenv.2010.10.021

Li, C., Li, Q. G., Dunwell, J. M., \& Zhang, Y. M. (2012). Divergent evolutionary pattern of starch biosynthetic pathway genes in grasses and dicots. Molecular Biology and Evolution, 29(10), 3227-3236. doi: 10.1093/molbev/mss131

Luchese, A. V., Gonçalves, A. C., Jr., Luchese, E. B., \& Braccini, M. C. L. (2004). Emergência e absorção de cobre por plantas de maize (Zea mays) em resposta ao tratamento de sementes com cobre. Ciência Rural, 34(6), 1949-1952. doi: 10.1590/S010384782004000600044

Luna, C. M., Casano, I. M., \& Trippi, V. S. (1997). Nitrate reductase is inhibited in leaves of Tricuma esticum treated with high levels of copper. Plant Physiology, 101(1), 103-108. doi: 10.1111/j.1399-3054.1997. tb01825.x

Maguire, J. D. (1962). Speed of germination aid in selection and evaluation for seedling emergence and vigor. Crop Science, 2(2), 176-177. doi: 10.2135/ cropsci1962.0011183X000200020033x
Malavolta, E. (1981). Manual de química agrícola: adubos e adubação. São Paulo, SP: Agronômica Ceres.

Mantovani, A. (2009). Composição química de solos contaminados por cobre: formas, sorção e feito no desenvolvimento de espécies vegetais. Tese de doutorado, Universidade Federal do Grande do Sul, Porto Alegre, RS, Brasil. Recuperado de https://www.lume.ufrgs.br/bitstream/handle/10183/ 17085/0007102 87.pdf?sequence $=1$

Marcos, J., F., \& Kikuti, A. L. P. (2006) Vigor de sementes de radish e desempenho de plantas em campo. Revista Brasileira de Sementes, 28(3), 4451. doi: 10.1590/S0101-31222006000300007

Mendes, A. M. S., Duda, G. P., Nascimento, C. W.A., Lima, J. A. G., \& Medeiros, A. D. L. (2010). Acúmulo de metais pesados e alterações químicas em Cambissolo cultivado com meloeiro. Revista Brasileira de Engenharia Agrícola e Ambiental, 14(8), 791-796. doi: 10.1590/S1415-43662010000800001

Moreira, A., \& Moraes, L. A. C. (2019). Soybean response to copper applied to two soils with different levels of organic matter and clay. Journal of Plant Nutrition, 42(18), 2247-2258. doi: 10.1080/019041 67.2019 .1655039

Nascimento, C. W. A., \& Fontes, R. L. F. (2004). Correlação entre características de Latossolos e parâmetros de equações de adsorção de cobre e zinco. Revista Brasileira de Ciência do Solo, 28(6), 965-971. doi: 10.1590/S0100-06832004000600004

Niva, C. C., Niemeyer, J. C., Silva Jr., F. M. R. D., Nunes, M. E. T., Sousa, D. L. de, Aragão, C. W. S.,... Römbke, J. (2016). Soil ecotoxicology in Brazil is taking its course. Environmental Science and Pollution Research, 23(11), 11363-11378. doi: 10.1007/s11356-016-6597-1

Penha, J. G., Carvalho, G. S., Abreu, L. B. de, Ribeiro, B. T., Souza Costa, E. T. de, \& Marques, J. J. (2017). Procedimentos para quantificação de elementostraço por espectrofotometria de absorção atômica em matrizes de interesse ambiental. (Boletim Técnico). Lavras, MG: Editora UFLA.

Rocheleau, S., Kuperman, R. G., Simini, M., Hawari, J., Checkai, R. T., Thiboutot, S.,... Sunahara, G. I. (2010). Toxicity of 2,4-dinitrotoluene to terrestrial plants in natural soils. Science of the Total Environment, 408(16), 3193-3199. doi: 10.1016/j. scitotenv.2010.04.010 
Rooney, C. P., Zhao, F. J., \& McGrath, S. P. (2006). Soil factors controlling the expression of copper toxicity to plants in a wide range of European soils. Environmental Toxicology and Chemistry, 25(3), 726-732. doi: 10.1897/04-602R.1

Santos, H. P., Melo, G. W. B., Luz, N. B., \& Tomasi, R. J. (2004). Comportamento fisiológicos de plantas de aveia (Avena strigosa) em solos com excesso de cobre. (Comunicado Técnico). Bento Gonçalves, RS: EMBRAPA.

Silva, J. P. S. D., Nascimento, C. W. A. D., Biondi, C. M., \& Cunha, K. P. V. D. (2012). Heavy metals in soils and plants in mango orchards in Petrolina, Pernambuco, Brazil. Revista Brasileira de Ciência do Solo, 36(4), 1343-1354. doi: 10.1590/S010006832012000400028

Singh, D., Nath, K., \& Sharma, Y. K. (2007). Response of wheat seed germination and seedling growth under copper stress. Journal of Environmental Biology, 28(2), 409-414.

Soil Survey Staff (2014). Keys to soil taxonomy. Washington, DC: USDA-Natural Resources Conservation Service.

Statsoft, I. S. (2004). Data Analysis Software System. Version 7.0.

Teixeira, P. C., Donagemma, G. K., Fontana, A., \& Teixeira, W. G. (Eds.). (2017). Manual de métodos de análise de solo. Brasília, DF: EMBRAPA.

Toselli, M., Baldi, E., Marcolini, G., Malaguti, D., Quartieri, M., Sorrenti, G., \& Marangoni, B. (2008). Response of potted grapevines to increasing soil copper concentration. Australian Journal of Grape and Wine Research, 15(1), 85-92. doi: 10.1111/j.1755-0238.2008.00040.x
United States Environmental Protection (2007). Agency method 3051A (SW-846): microwave assisted acid digestion of sediments, sludges, and oils. Washington: USEPA.

Van Vlaardingen, P. L. A., Traas, T. P., Wintersen, A., \& Aldenberg, T. (2004). ETX 2. 0: a program to calculate hazardous concentrations and fraction affected, based on normally distributed toxicity data. Bilthoven, BA: RIVM.

Verbruggen, E. M. J., Posthumus, R., \& Van Wezel, A. P. R. (2001). Ecotoxicological serious risk concentrations for soil, sediment and (ground) water: updated proposals for first series of compounds. Bilthoven, BA: RIVM.

Warne, M. S. J., \& Van Dam, R. (2008). NOEC and LOEC data should no longer be generated or used - Opinion Piece. Australasian Journal of Ecotoxicology, 14(1), $1-5$.

Xu, J., Yang, L., Wang, Z., Dong, G., Huang, J., \& Wang, Y. (2006). Toxicity of copper on rice growth and accumulation of copper in rice grain in copper contaminated soil. Chemosphere, 62(4), 602-607. doi: 10. 1016/j.chemosphere.2005.05.050

Yruela, I. (2005). Copper in plants. Brazilian Journal of Plant Physiology, 17(1), 145-146. doi: 10.1590/S16 7704202005000100012 